\title{
The Determinants of South African Banks' Capital Buffers
}

\author{
Athenia Bongani Sibindi \\ Finance, Risk Management and Banking, University of South Africa, South Africa \\ sibinab@unisa.ac.za
}

\begin{abstract}
The financing decisions of banks remain an enigma, increasingly attracting the attention of banking regulators and corporate finance scholars alike. The 'buffer view' of bank capital is premised on the notion that banks keep capital in excess of the regulatory requirements in line with bank specific factors. This study sought to test the 'buffer view' of bank capital. Utilising a sample of 16 South African banks for the period 2006-2015, panel data techniques were employed to estimate a fixed effects model to test the relationship between buffer capital and the firm level determinants of capital structure. It was established that the risk and size variables were negatively related to the buffer capital variable, whilst the dividend variable was positively related. This was consistent with the predictions of the buffer view of capital. The findings lend credence to the 'buffer view' school of thought about bank capital. These findings are also inconsistent with bank capital regulations solely determining the capital structures of banks but epitomises some measure of voluntary capital structure decision making by banking firms.
\end{abstract}

Keywords: Bank, Capital structure, Firm level, Buffer, South Africa

\section{Introduction}

Banks play a critical role in intermediation in any economy. It is for this reason that their financial well-being is a subject that attracts the attention of monetary authorities. The main thrust of the financial regulation of banks is to ensure the safety and financial soundness of the banking sector. At worst, the financial problems bedevilling a banking institution could precipitate a bank run. The failure of a large bank, then, can cause psychological contagion, leading depositors to start runs on other banks (Hart \& Zingales, 2011: 3). This is a situation whereby the depositors will 'panic' and withdraw their funds in anticipation of the bankruptcy and demise of their banking institution. As the banking institutions are interconnected, the demise of one banking institution can result in a contagion effect, resulting in the distress of other banking institutions. Bank runs cause real economic problems because even 'healthy' banks can fail, causing the recall of loans and the termination of productive investment (Diamond \& Dybvig, 1983: 402). Suffice to highlight that there is systemic risk posed by the failure of one banking institution. As such, monetary authorities have a vested interest in regulating the banking sector. Therefore, the attainment of a safe and financially sound banking sector is predicated on the establishment of an effective financial regulatory regime. The two approaches that are at the disposal of monetary authorities are the micro-prudential and the macro-prudential regulatory regimes. The former regime involves the bank regulator specifically tailoring an individualistic regulatory response for each banking firm, while the latter regime involves the bank regulator taking a holistic view of banking regulation and promulgating standardised regulations for the entire industry.

To achieve the objective of fostering a financial sound banking sector, various capital regulations have been promulgated over the years, starting with Base I Accord in 1988 to the present day Basel III regulatory framework. These provisions amongst other laid the minimum capital requirements that should be observed by banks. Notwithstanding, a growing strand of empirical studies have demonstrated that banks keep capital in excess of the regulatory minimum (refer to, among other scholars, Berger, Herring and Szegö, 1995; Berger, DeYoung, Flannery, Lee \& Öztekin, 2008; Besanko \& Kanatas, 1996; Gropp \& Heider, 2010; Muneer et al., 2011). The 'buffer view' of bank capital contends that banks seek to keep capital in excess of the prescribed regulatory minimum requirements. Several reasons have been advanced in support of the hypotheses that banks keep buffer levels of capital. Firstly, it has been argued that banks keep buffer capital for fear of regulation sanction should they deviate below the minimum threshold. Secondly, banks keep buffers to insulate themselves against the insolvency risk. Thirdly, buffers act as a cushion for banks to mitigate adverse business and economic cycles. It is instructive to note that the importance of buffer capital has been acknowledged and enshrined in the Basel III Accord.It was enshrined in the accord that banks are required to reduce procyclicality and promote countercyclicality by introducing capital conservation and countercyclical buffers to curtail systemic risk. Fourthly, banks hold buffer capital as a risk absorption 
mechanism. This ensures that bank can grow their loan books with the necessary capital to absorb the additional loan portfolio risk. Fifthly, banks may be motivated to keep excess levels of capital if the adjustment costs are prohibitive. Sixthly, the buffer view may also be explained by information asymmetry that might exist in bank financing. For instance, dividend-paying, high-growth, profitable and large banks are rated favourably by the equity market and hence can issue equity at short notice. As such, they can hold low levels of capital (Gropp \& Heider, 2010: 595). The empirical studies have also demonstrated that the firm level determinants of capital structure also have a predictive power on bank buffer. As such, bank buffers are dependent on bank characteristics such as size, growth and profitability, among other factors.

The principal motivation behind this study was to test the 'buffer view' of bank capital within the context of a developing country and also incorporating the 2007 to 2009 global financial crises. South Africa was employed as the test case, due to its developed financial system notwithstanding that it is a developing country. Unlike previous studies on bank buffers, this study took cognisance of the fact that banks rely on one another in their financing of operations through their interaction in the inter-bank market. As such this study tested and corrected for cross-sectional dependenceand utilised the Driscoll and Kray (1998) estimator which produces heteroskedasticity and autocorrelation- consistent standard errors that are robust to general forms of spatial and temporal dependence. This study extends the existing knowledge in that it was conducted within a developing country context, an area which has been under-researched. The study also offers insight as to the effect of the global financial crises on bank buffers. The rest of the article is organised as follows: the next section reviews the related literature. Section 3 discusses the research methodology employed. Section 4 presents and discusses the empirical findings and Section 5 concludes.

\section{Literature Review}

Banking regulation and buffer capital: The regulation of banking firms may promote or curtail the banks from operating at their desired target capital structure. According to Ahmad and Abbas (2011: 201), following mandatory bank capital standard requirements, banks are involved in both voluntary and involuntary capital structure decisions. They go on further to observe that voluntary capital structure decisions of banks are considered the same as in non-financial settings; same theories and determinants of capital structure are applied to decisions relating capital structure. Involuntary capital structure decisions are enforced on the banks by regulatory authorities after deviating from the prescribed and adequacy capital requirements as directed by the regulators. The motivation behind the holding of buffer capital is one such voluntary capital structure decision by banks, which continues to baffle researchers and regulators alike. Several reasons have been advanced in attempting to address the rationale behind banks keeping buffer capital. Buffer capital may be defined as the amount of capital that banks hold in excess of the minimum regulatory capital requirement. Berger et al. (1995:8) contend that banks may hold a substantial buffer of additional capital as financial slack so that they can borrow additional funds quickly and cheaply in the event of unexpected profitable investment opportunities. Similarly, such a buffer of capital protects against costly unexpected shocks to capital if the financial distress costs from low capital are substantial and the transactions costs of raising new capital quickly are very high. Buffer capital can further act as a cushion, absorbing costly unexpected shocks, particularly if the financial distress costs from low capital, and the costs of accessing new capital quickly, are high (Jokipii and Milne, 2008:13). Proponents of the "buffer capital view" argue that banks hold capital as a buffer against insolvency. As such, banks have an incentive to avoid failure through a variety of means, including holding a capital buffer of sufficient size, holding enough liquid assets, and engaging in risk management (Cebenoyan and Strahan, 2004:2). The impact of regulation has banks holding capital buffers, or discretionary capital, above the regulatory minimum in order to avoid the costs associated with having to issue fresh equity at short notice (Gropp and Heider, 2010:595). In essence by holding capital as a buffer, banks essentially insure themselves against costs related to market discipline or supervisory intervention in the event of a violation of the requirements.

The empirical evidence in support of the buffer capital view has been mixed. In support, amongst others, Gambacorta and Mistrulli (2004:443) find evidence that for all kinds of banks the buffer capital has always been much greater than zero. They reason that this is consistent with the hypothesis that capital is difficult to adjust and banks create a cushion against contingencies. Koziol and Lawrenz (2009:871) also find evidence that banks do not hold the minimum capital but have voluntary capital buffers. Harding, Liang and Ross 
(2013) find evidence that there exists an interior optimal capital ratio for banks with deposit insurance, a minimum capital ratio and bank franchise value. They reason that banks voluntarily choose to hold capital in excess of the required minimum. Allen, Carletti and Marquez (2011) and Jacques and Nigro (1997) also find evidence that banks will hold buffer capital in excess of regulatory requirements. There is another strand of literature that does not find support for the buffer view of capital. Gropp and Heider (2010:589) observe that high levels of banks' discretionary capital do not appear to be explained by buffers that banks hold to insure against falling below the minimum capital requirement. Moreover, banks that would face a lower cost of raising equity at short notice (profitable, dividend paying banks with high market to book ratios) tended to hold significantly more capital. Teixeira, Silva, Fernandes and Alves (2014:56) also fail to find evidence in support of the buffer view. It is also instructive to note that the conservation of buffer capital has been instituted in the Basel III accord regardless of the unresolved debates. Suffice to conjecture that the advantages of banks keeping buffer capital outweigh the disadvantages. According to BIS (2010:9) the purpose of a buffer is to provide capital sufficient for a banking company to withstand downturn events and still remain above its regulatory minimum capital requirement.

As has been demonstrated hitherto, capital requirements and deposit insurance are the two regulatory instruments that are in the armoury of the banking regulator which could have a bearing on capital structure choices of banking firms. Gropp and Heider (2010:589) set out to establish whether capital requirements are indeed a first-order determinant of banks' capital structure. They employed cross-section and time-series variation in a sample of large, publicly traded banks spanning 16 countries, namely; the United States and 15 countries of the European Union from 1991 until 2004. They also sought to establish whether deposit insurance determines the capital structure of banking firms. To the contrary they established that neither capital regulation nor deposit insurance is a first order determinant of capital structure of banks. They reason that the implication is that capital regulation is not binding. They also report similarities in the determinants of capital structures of banks and non-financial firms. Teixeira et al. (2014:34) also set out to establish whether regulation is a first order determinant of bank capital structure. They employed panel data of a sample of 560 banks, 379 from the U.S.A. and 181 from Europe, spanning 23 countries, for the period 20042010. They found that the factors affecting the capital structure of non-financial firms play an important role in explaining banks' capital structure. They reason that this suggested that regulation may not be a first order determinant of banks' share of equity capital. They also document a strong similarity in the factors affecting the capital structure of banks and those of non-financial firms.

The above foregoing suggests that banking regulation determines capital structure to a certain extent. Banking firms would stock up capital motivated by a variety of reasons, chief amongst them being fear of regulatory sanction, as well as the costs associated with raising capital at short notice should it fall below the required minimum. However, there are studies that have documented that the buffer capital stocked by banking firms is in excess and is inexplicable in-terms of providing cushion against the regulatory minimum. It has also been demonstrated that capital regulation might not necessarily be a first order determinant of bank capital structure but of secondary importance. This is a test for the efficacy of bank capital regulation. The implication is that the minimum capital requirements set for banks may not be binding in such a scenario. The majority of the studies also discount the moral hazard hypothesis of deposit insurance-that banks would seek to take advantage of mispriced deposit insurance. Also deposit insurance does not show up as a primary determinant of capital structure.

Credit risk management: Banks manage credit risk in a variety of ways. The principal methods employed by banks to manage risks of their loan portfolio include the purchasing of credit derivatives as well as securitisation. One strand of literature has explored the relationship between risk management and capital structure of banking institutions. This has been premised on the notion that banks that actively manage their credit risk through, for instance the loan sales market (securitisation) are bound to keep lower levels of capital as compared to the banks that manage the credit risk passively. The second strand of literature advances the risk absorption hypothesis. Proponents of this view posit that bank capital absorbs risk and expands banks' risk-bearing capacity. The first strand of literature focuses on the relationship between credit risk management and capital structure choices. Amongst these scholars, Cebenoyan and Strahan (2004:2) using a sample of all domestic commercial banks in the United States of America, test whether banks that are better able to trade credit risks in the loan sales market experience significant benefits. They find evidence 
that banks that purchase and sell their loans (their proxy for banks that use the loan sales market to engage in credit-risk management) hold a lower level of capital per dollar of assets than banks not engaged in loan buying or selling. They also document that banks that operate on both sides of the loan sales market also hold less capital than either banks that only sell loans but do not buy them, or banks that only buy loans but do not sell them. They reason that this difference is important because it suggests that the active rebalancing of credit risk - buying and selling rather than just selling (or buying) - allows banks to alter their capital structure. Further they posit that their results also suggest that banks use the risk-reducing benefits of risk management to take on more profitable but higher risk activities to operate with greater financial leverage. Froot and Stein (1998:1) demonstrate that at the same time that banks are investing in illiquid assets, most banks also appear to engage in active risk management programs. They postulate that, holding fixed its capital structure, there are two broad ways in which a bank can control its exposure to risk. First, some risks can be offset simply via hedging transactions in the capital market. Second, for those risks where direct hedging transactions are not feasible, the other way for the bank to control its exposure is by altering its investment policies. Therefore, with illiquid risks, the bank's capital budgeting and risk management functions become linked.

The second strand of literature tests the risk absorption hypothesis. Amongst these scholars, Allen, Carletti and Marquez (2011:36) develop a model that demonstrates that when banks directly finance risky investments, they hold a positive amount of equity capital as a way to reduce bankruptcy costs and always prefer to diversify if possible. In contrast, when banks provide loans to non-financial firms that invest in risky assets, diversification is not always optimal. Berger et al. (2008:3784) examine bank liquidity creation by employing a sample including almost all commercial banks in the United States that are in business during the period 1993 to 2003. They find that for large banks, the relationship between capital and liquidity creation is positive, consistent with the expected empirical dominance of the "risk absorption" effect. In sharp contrast, for small banks, the relationship between capital and liquidity creation is negative, consistent with the expected dominance of the "financial fragility crowding out" effect for these institutions. The relationship is not significant for medium banks, suggesting that the two effects cancel each other out for this size class. Credit risk management attaches much importance in the formulation of capital structure policies of banking organisations. It has been demonstrated that those banking institutions that actively manage credit risk will be much inclined to keep lower levels of buffer capital in comparison to those who do not actively manage the risk. On the other hand, the risk absorption hypothesis predicts that large banks are most likely to keep higher levels of buffer capital in order to be best placed in absorbing more risks, as they grow their loan book.

\section{Data and Methodology}

Sample description and data Sources: The population for this study comprised of South African banking institutions both listed and not listed on the Johannesburg Stock Exchange. All the banks with complete data sets for the ten-year period running from 2006 to 2015 were considered for this study. There were 16 such banks. The Bureau van DijkBankscope database was used to source the audited financial statements of the banks.

\section{Variable definition}

Dependent variable: The dependent variable employed in this regard is the excess of Tier 1 regulatory capital ratio over the prescribed Tier 1 regulatory capital ratio (BUFFER).

Independent variables: The independent variables consisted of the firm level determinants of capital structure as well as dummy variables. The firm level determinants of capital structure that are reliably important and were considered for this study are size, growth, profitability, asset tangibility and credit risk. Dummy variables were employed for this study are to capture the effects of the 2007-2009 financial crises as well as to capture one remaining firm level determinant of capital structure-dividends.

- Size: To measure size the natural logarithm of total assets was employed. There is a direct relationship between size and the value of assets held. Larger companies are expected to have more assets. Most studies on the determinants of capital structure have employed this proxy to measure size. Such studies include, Al-Najjar and Hussainey (2011); Antoniou, Guneyand Paudyal (2008); 
Booth, Aivazian, Demirguc-Kuntand Maksimovic (2001); Frank and Goyal (2009); Mukherjee and Mahakud (2010) and Oztekin and Flannery (2012) amongst others.

- Growth: The growth variable was defined as the annual growth rate of total assets. We took cue from Titman and Wessels (1998) and Anarfor (2015) amongst others, in defining growth as such. The reasoning is that the higher the growth rate, the higher the growth prospects of the company. The alternative definition which has also been used widely in empirical studies would have been to proxy growth prospects with the market-to-book value ratio (see amongst others, Booth et al., (2001; Frank and Goyal, 2009; and Teixeiraet al., 2014).

- Asset tangibility: In this study asset tangibility was defined as the ratio of fixed assets to total assets. The ratio of fixed assets to total assets expresses the collateral value. Fixed assets offer collateral value. If collateral value is high, the firm would be viewed in good light in the debt market. As such it could access loans at concessionary rates. The fixed assets to total assets ratio was employed as a proxy for asset tangibility as extant studies have utilised this measure. The empirical studies that have employed this measure include Rajan and Zingales (1995); Frank and Goyal (2009); Mukherjee and Mahakud (2010); Oztekin and Flannery (2012) and De Jonghe and Oztekin (2015) amongst others.

- Profitability: Various measures have been employed in empirical studies to capture the effect of profitability. This is partly because profitability is defined in several ways. In this study we employ the return on assets (ROA) measure as the proxy for profitability. Boot et al. (2001) and Anarfor (2015) amongst others, employ ROA as an indicator of profitability in similar studies. In the case of the banks this is defined as the return on average assets (ROAA).

- Risk: The proxy that we employ for risk measures bank credit risk. It is defined as the ratio of impaired loans to gross loans.

- Dummy variables: Two dummy variables were utilised in this study. The first one was the dummy variable (DIVIDEND) for dividend payers. It was defined as one, when a bank paid out a dividend and zero when the bank did not declare a dividend. The second dummy variable (GFC) was to capture the effects of the financial crises. It was defined as one for the years when the financial crisis occurred and zero otherwise.

Empirical model specification and estimation techniques: To examine the relationship between buffer and the firm-level determinants of capital structure, a static panel data model was employed. Diagnostics tests were performed to ensure that the model was well specified and in order to select the most appropriate estimation technique to run the regression. The econometric analysis was conducted by employing Stata version 14 software.

The static panel data model was specified as follows:

$\operatorname{Xre}_{i, t}=\boldsymbol{x}_{i, t}^{\prime} \boldsymbol{\beta}+\alpha_{i}+\varepsilon_{i, t}(1)$

Where:

$X r e_{i, t}=$ buffer capital for banking firm $i$ at time $t$.

$\boldsymbol{x}_{i, t}^{\prime}=$ a vector of explanatory variables (size, profit, growth, asset tangibility, dividend, risk and GFC) for banking firm iat time $t$.

$\beta=$ a vector of slope parameters

$\alpha_{i}=$ group-specific constant term which embodies all the observable effects.

$\varepsilon_{\mathrm{i}, \mathrm{t}}=$ composite error term which also takes care of other explanatory variables that equally determines leverage but are not included in the model. Equation (1) was estimated using the fixed effects with Driscoll and Kray (1998) standard errors estimator, which controls for cross-sectional dependence and heteroscedasticity which were the characteristics of this data set.

\section{Empirical Results}

Summary statistics: This section presents the summary statistics of all the variables that were used. The trends of the variables over time are also described. The descriptive statistics of the variables are presented 
in Table 1: These are the central measures of tendency (mean and median), standard deviation, minimum and maximum values for the sample of banking firms under consideration.

Table 1: Summary statistics of the variables

\begin{tabular}{llllll}
\hline Variable & Mean & Median & Standard Deviation & Minimum & Maximum \\
\hline Buffer Capital & 0.0957 & 0.0688 & 0.1135 & -0.2600 & 1.0561 \\
Growth & 0.1592 & 0.1199 & 0.1962 & -0.5775 & 1.1195 \\
Profit & 0.0191 & 0.0134 & 0.0380 & -0.1694 & 0.2036 \\
Asset & 0.0102 & 0.0089 & 0.0083 & 0.0005 & 0.0400 \\
Tangibility & 0.0528 & 0.0249 & 0.0870 & -0.0528 & 0.6878 \\
Risk & 10.8500 & 8.7100 & 5.0200 & 6.1800 & 27.5700 \\
Size & 0.6500 & 1 & 0.4785 & 0 & 1 \\
Dividend & 0.3000 & 0 & 0.4597 & 0 & 1 \\
GFC &
\end{tabular}

Note: GFC is the dummy variable representing the 2007-2009 global financial crises.

South African banks on average experienced a mean year-on-year growth of $15.9 \%$ of their total assets. They also realised profits with a mean return of assets (ROA) of $1.9 \%$. This is modest in comparison to nonfinancial firms. Ramjee and Gwatidzo (2012:59) in comparison report a mean ROA of 17\% for their sample of non-financial firms. The mean asset tangibility level of banks was one percent of total assets. This implies that on average one percent of South African banks' total assets consisted of fixed assets. The average size of the bank approximated by the natural logarithm of total assets is 10.85 . On average on any given year, $65 \%$ of the banks paid dividends. South African banks store buffer levels of capital. Buffer capital is defined as the excess of the actual Tier 1 regulatory capital over the regulated minimum Tier 1 regulatory capital. The variation in this buffer is exhibited in Figure 1. On average, banks have maintained buffer capital levels ranging between $7 \%$ and $11 \%$.

Figure 1: The variation of buffer capital

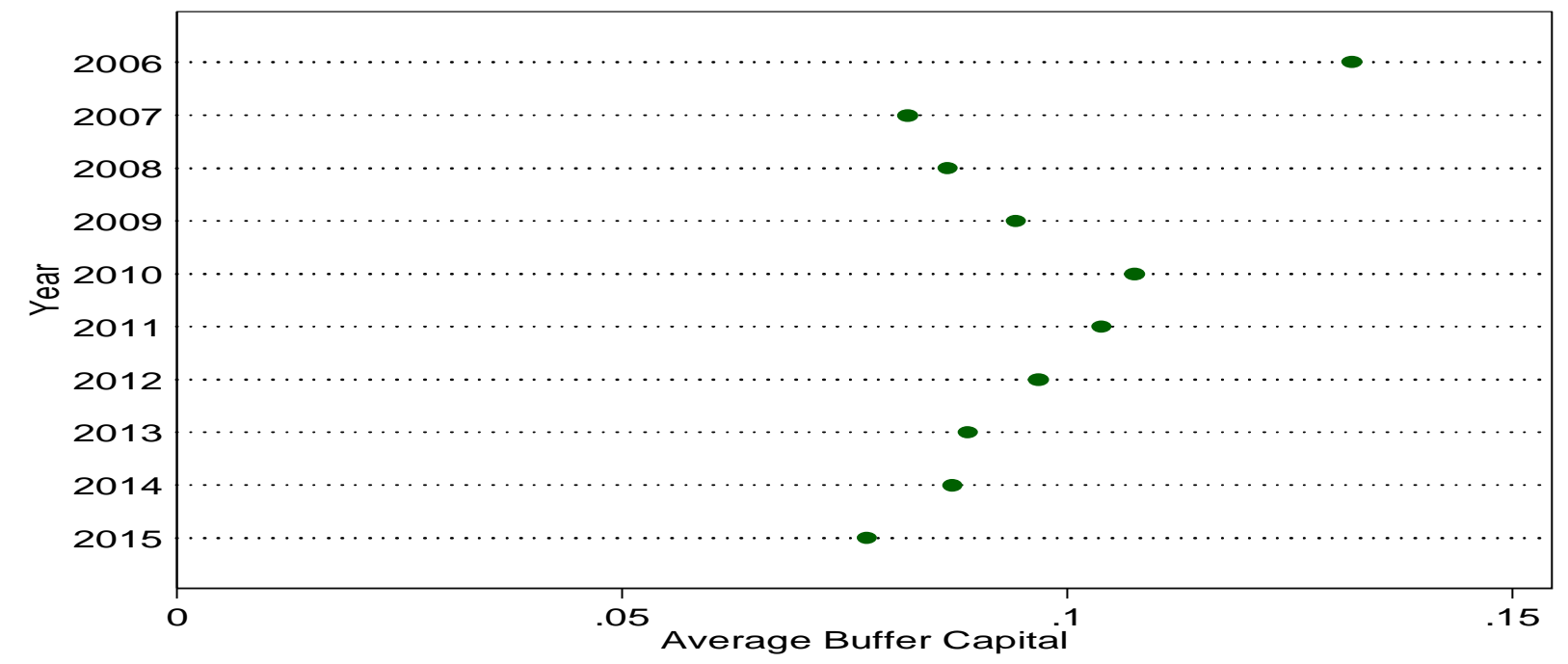

Correlation analysis: The correlations of buffer capital and the firm level determinants of capital structure are documented in Table 2. 
Table 2: Correlation matrix of buffer capital and the main variables used in this study

\begin{tabular}{llllllll}
\hline & Buffer Capital & Growth & Profit & Asset & Risk & Size & Dividend \\
\hline Buffer Capital & 1.000 & & & & & & \\
Growth & -0.068 & 1.000 & & & & & \\
Profit & $0.284^{* * *}$ & $0.411^{* * *}$ & 1.000 & & & & \\
Asset & $0.157^{* *}$ & 0.131 & $0.261^{* * *}$ & 1.000 & & & \\
Risk & -0.001 & 0.047 & $-0.178^{* *}$ & 0.123 & 1.000 & & \\
Size & $-0.284^{* * *}$ & -0.127 & $-0.209^{* * *}$ & -0.027 & -0.004 & 1.000 & \\
Dividend & 0.052 & -0.069 & 0.002 & $-0.143^{*}$ & $-0.196^{* *}$ & $0.188^{* *}$ & 1.000 \\
\hline
\end{tabular}

$\left({ }^{*}\right) /\left({ }^{* *}\right)$ and $\left({ }^{* * *}\right)$ indicates the (10\%), (5\%) and (1\%) level of significance respectively. The variables are defined as follows: Buffer Capital= Tier1 Regulatory Capital ratio - Prescribed Tier 1 Regulatory Capital ratio; Growth=growth rate of Total Assets; Profit= Return on Average Assets (ROAA); Size= natural logarithm of Total Assets;

Asset (Asset tangibility) =Fixed Assets/Total Assets; Credit risk= Impaired Loans/Gross Loans; Dividend = dummy variable $=(1$ when dividend is paid and, 0 when dividend is not paid $)$.

Profit is positively correlated with buffer capital. Highly profitable banks keep more levels of capital in excess of the regulatory requirement. This is consistent with the predictions of the buffer view of capital. Asset tangibility is positively correlated to buffer capital. This implies that banks that have more tangible assets stock more capital. This is consistent with the buffer view of capital. Lastly, size is negatively correlated to buffer capital. Small banks are inclined to keep more levels of capital in comparison to large banks. This is because they have not generated goodwill to readily shore up capital in the equity or debt markets at short notice, should the need arise, as compared to the large banks.

Panel regression diagnostics: Initial diagnostics tests were conducted in order to estimate a robust model to test the relationship between buffer capital and the firm level determinants of capital structure. The results are reported in Table 3.

Table 3: Initial diagnostic tests

\begin{tabular}{|c|c|c|c|}
\hline Test & $\begin{array}{l}\text { Test } \\
\text { Statistic }\end{array}$ & Critical Value & Inference \\
\hline $\begin{array}{l}\text { Joint validity of cross-sectional } \\
\text { individual effects } \\
H_{0}: \boldsymbol{\alpha}_{\mathbf{1}}=\boldsymbol{\alpha}_{\mathbf{2}}=\cdots \boldsymbol{\alpha}_{N-\mathbf{1}}=\mathbf{0} \\
H_{A}: \boldsymbol{\alpha}_{\mathbf{1}} \neq \boldsymbol{\alpha}_{\mathbf{2}} \neq \cdots \boldsymbol{\alpha}_{N-1} \neq \mathbf{0}\end{array}$ & $F=9.55$ & $7)=4.142$ & Cross-sectional specific effects are valid. \\
\hline $\begin{array}{l}\text { Joint validity of time effects } \\
H_{0}: \lambda_{1}=\lambda_{2}=\lambda_{n-1}=\mathbf{0} \\
H_{A}: \lambda_{1} \neq \lambda_{2} \neq \cdots \lambda_{n-1} \neq \mathbf{0}\end{array}$ & $\mathrm{F}=0.62$ & $\mathrm{~F}_{(0.01,9,129)}=2.548$ & $\begin{array}{l}\text { Time effects are invalid. The error term } \\
\text { takes a one-way error component form. }\end{array}$ \\
\hline $\begin{array}{l}\text { Breusch Pagan (1980) LM test } \\
\text { for random effects } \\
H_{0}: \boldsymbol{\delta}_{\boldsymbol{\mu}}{ }^{2}=\mathbf{0} \\
H_{A}: \boldsymbol{\delta}_{\boldsymbol{\mu}}{ }^{2} \neq \mathbf{0}\end{array}$ & $\mathrm{LM}=12.23$ & $\chi_{(15)}^{2}=5.23$ & $\begin{array}{l}\text { There is significant difference in } \\
\text { variance across the entities. Random } \\
\text { effects are present. }\end{array}$ \\
\hline $\begin{array}{l}\text { Hausman (1978) specification } \\
\text { test }\end{array}$ & $\mathrm{m}_{3}=70.17$ & $\chi_{(6)}^{2}=0.873$ & $\begin{array}{l}\text { Regressors not exogenous. Hence the } \\
\text { Fixed effects specification is valid. }\end{array}$ \\
\hline
\end{tabular}




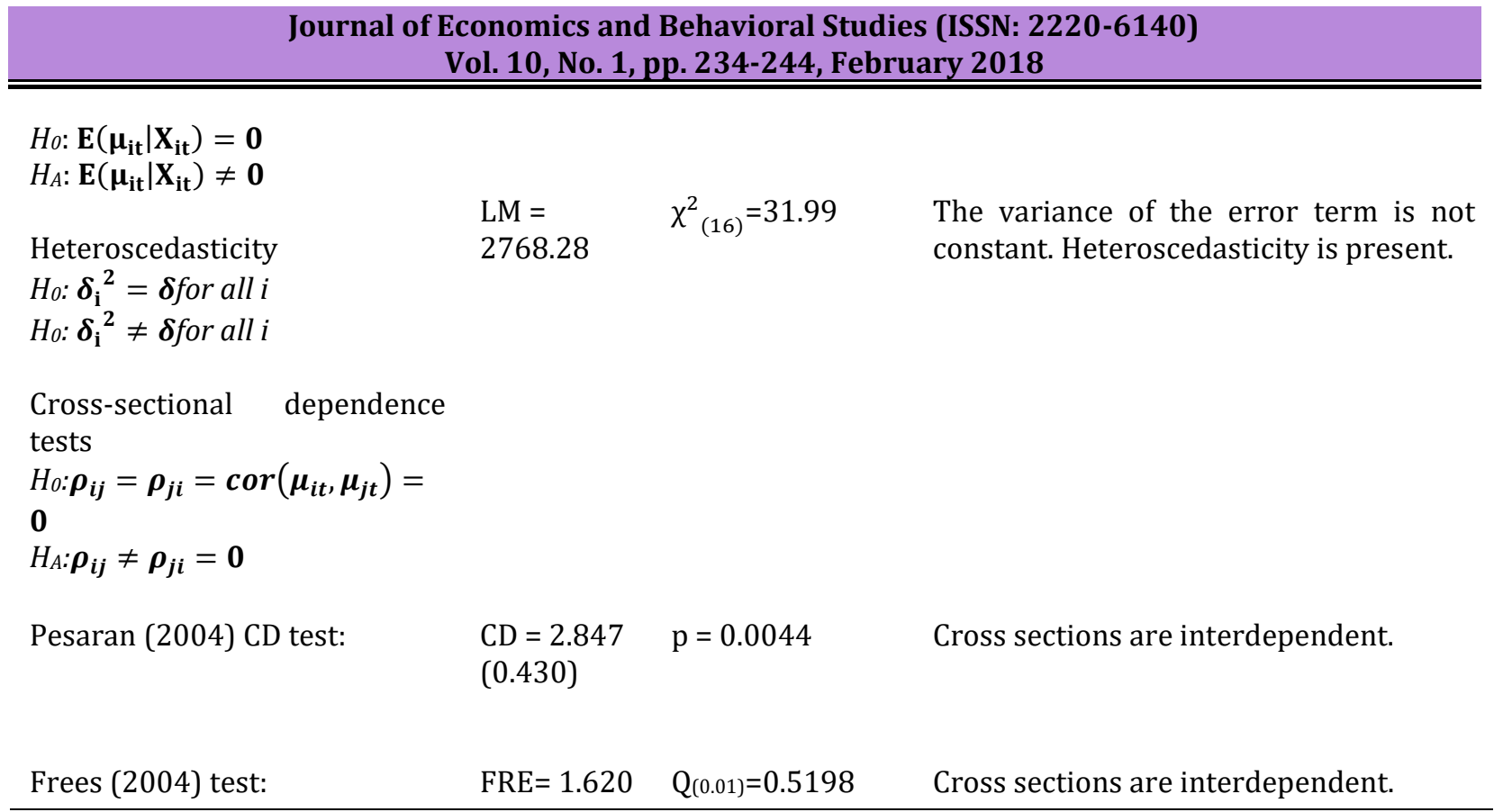

The diagnostics confirmed the validity of fixed effects, absence of time effects, interdependence of crosssections, presence of random effects and heteroscedasticity. In the absence of time effects, a one-way model is specified. Subsequently, the FE estimator is applied. However, in order to avert estimation inefficiency rendered by the detected cross-sectional dependence and heteroskedasticity, estimation was done within the framework of Driscoll and Kray (1998). According to Hoechle (2007:282), the Driscoll and Kray (1998) estimator produces heteroskedasticity and autocorrelation- consistent standard errors that are robust to general forms of spatial and temporal dependence.

Panel regression results: Having run the initial diagnostics, the model was estimated. The results of the regression of the firm level determinants of capital structure on buffer capital are reported in Table 4. These results are premised on testing the hypothesis stated as follows: Bank leveraging is consistent with the buffer view of capital.

Table 4: Panel regression results with buffer capital and Tier 1 capital as the dependent variables

\begin{tabular}{ll}
\hline Explanatory Variable & Fixed Effects with Driscoll and Kray (1998) standard errors \\
\hline Growth & -0.147 \\
& $(-1.70)$ \\
Profit & -0.585 \\
& $(-1.12)$ \\
Asset Tangibility & 1.731 \\
& $(0.68)$ \\
Risk & $-0.997^{* * *}$ \\
& $(-4.21)$ \\
Size & $-0.042^{* *}$ \\
& $(-2.97)$ \\
Dividend & $0.076^{*}$ \\
& $(2.10)$ \\
GFC & $-0.025^{* *}$ \\
& $(-3.09)$ \\
constant & $0.584^{* * *}$ \\
& $(3.93)$ \\
Adjusted $\mathrm{R}^{2}$ & 0.4182 \\
\hline (t) $/\left(^{* *}\right)$ and $\left(^{* * *}\right)$ indicates the $(10 \%),(5 \%)$ and $(1 \%)$ level of significance respectively. The t-statistics for \\
the fixed effects model are reported in parentheses.
\end{tabular}


The table above shows the results of estimating the following regression for the sample of 16 South African banks for the period 2006-2015.

$$
\mathrm{Xre}_{i, t}=\boldsymbol{x}_{i, t}^{\prime} \boldsymbol{\beta}+\alpha_{i}+\varepsilon_{i, t}
$$

Where: the dependent variable $=$ BUFFER $=X r e_{i, t} ; \boldsymbol{x}_{i, t}^{\prime}=$ a vector of explanatory variables (size, profitability, growth, asset tangibility, dividend, credit risk and GFC) for bank $i$ at time t; $\beta=$ a vector of slope parameters; $\alpha_{i}=$ group-specific constant term which embodies all the observable effects.

$\varepsilon_{\mathrm{i}, \mathrm{t}}=$ composite error term which also takes care of other explanatory variables that equally determines buffer capital but are not included in the model.

The estimated results document four statistically significant results. Firstly, bank credit risk was negatively related to buffer capital and the result is statistically significant at the $1 \%$ level of significance. Banks with high credit risk keep low buffer capital in comparison to banks with less credit risk. Secondly, size is negatively related to buffer capital and the result is statistically significant at the $5 \%$ level of significance. Arguably, large banks are keeping low levels of capital because of the ease with which they can raise capital in the event that they deviate from the prescribed levels. Thirdly, the dividends variable is positively related to buffer capital. The relationship is statistically significant at the $10 \%$ level of significance. Dividend paying banks are keeping high buffer capital levels as compared to non-dividend paying banks. We reason that this phenomenon could perhaps be best explained by the signalling theory. Dividend paying banks send out the signal that their prospects are good and hence are viewed favourably by the debt and equity markets. Thus they are able to shore up their capital levels with much ease. Lastly, buffer capital is negatively associated with the global financial crises dummy variable. This corroborates the findings of Jokipii and Milne (2008:1450) who find a negative relationship between buffer capital and cycle.

Table 5 draws comparisons between the predicted and estimated effects of the regression of the buffer capital variable on the firm level determinants of capital structure. Suffice to highlight that by and large, the financing of South African banks conforms to the buffer view of capital as the predicted results are in line with the estimated results for dividends, size and risk. This diminishes the role of regulation as being the first-order determinant of capital structure. The findings lend credence to the 'buffer view' school of thought about bank capital. These findings are also inconsistent with bank capital regulations solely determining the capital structures of banks but demonstrate that banks also voluntarily determine their capital structures subject to their bank specific attributes.

Table 5: Predicted effect versus estimated effect of firm level factor on buffer capital

\begin{tabular}{lll}
\hline Firm Level Determinant & Predicted Effect & Results of this Study \\
\hline Profitability & Positive & Insignificant \\
Asset tangibility & No prediction & N/A \\
Growth & Positive & Insignificant \\
Dividends & Positive & Positive \\
Size & Positive/Negative & Negative \\
Risk & Negative & Negative \\
\hline
\end{tabular}

\section{Conclusion and Recommendations}

This study examined the "buffer view" of bank capital. The main view being tested was whether firm level determinants of capital structure have a predictive power on the banks stocking capital in excess of the regulatory minimum. The study controlled for cross-sectional dependence emanating from the dependence of banks on one another for financing. The fixed effects with Driscoll and Kray (1998) standard errors estimator was utilised to estimate a fixed effects model to test the relationship between buffer capital and the firm-level determinants of capital structure. Moderate support was found in favour of the buffer view school of thought. When the buffer capital variable was regressed on the firm level determinants of capital structure, it was found that the estimated results were consistent with the predictions of the buffer view. Specifically, the dividends variable was positively related to buffer capital, whilst size and risk were negatively related to buffer capital. This further diminishes the regulatory view of bank capital. The results also confirmed that the GFC was negatively related to buffer capital. In essence the South African bank capital buffers were eroded to 
mitigate the effects of the GFC.The implication of these finding is that South African banks are financial sound. Notwithstanding as the monetary authorities grapple with the implementation of Basel III framework, we would like to offer some policy advise. Firstly, it would be prudent for regulatory authorities to expedite the institution of deposit-protection insurance to increase the safety nets available for depositors. Secondly it is advisable that the Basel III requirements be adapted to be in synch with the requirements of the South African banking sector as opposed to the current scenario of one-size-fits-all.

\section{References}

Ahmad, F. \& Abbas, Z. (2011). Role of Firm's level characteristics in determining the capital structure of Banks: Evidence from the Pakistan Banks. Interdisciplinary Journal of Contemporary Research in Business, 2(12), $201-216$.

Allen, F., Carletti, E. \& Marquez, R. (2011). Credit market competition and capital regulation. Review of Financial Studies, 24(4),983-1018.

Al-Najjar, B. \& Hussainey, K. (2011). Revisiting the capital-structure puzzle: UK evidence. The Journal of Risk Finance, 12(4),329-338.

Anarfo, E. B. (2015). Determinants of capital structure of banks: Evidence from sub-Sahara Africa. Asian Economic and Financial Review, 5(4), $624-640$.

Antoniou, A., Guney, Y. \& Paudyal, K. (2008). The determinants of capital structure: capital market-oriented versus bank-oriented institutions. Journal of Financial and Quantitative Analysis, 43(01), 59-92.

Berger, A. N., DeYoung, R., Flannery, M. J., Lee, D. \& Öztekin, Ö. (2008). Why do large banking organizations hold so much capital? Journal of Financial Services Research, 34(2/3), 123-149.

Berger, A. N., Herring, R. J. \& Szegö, G. P. (1995). The role of capital in financial institutions. Journal of Banking \& Finance, 19(3), 393-430.

Besanko, D. \& Kanatas, G. (1996). The regulation of bank capital: Do capital standards promote bank safety? Journal of Financial Intermediation, 5(2), 160-183.

BIS (Bank for International Settlements). (2010). Basel III: A global regulatory framework for more resilient banks and banking systems. Basle.

Booth, L., Aivazian, V., Demirguc-Kunt, A. \& Maksimovic, V. (2001). Capital structures in developing countries. The Journal of Finance, 56(1), 87-130.

Breusch, T. S. \& Pagan, A. R. (1980). The Lagrange multiplier test and its applications to model specification in econometrics. The Review of Economic Studies, 47(1), 239-253.

Cebenoyan, A. S. \& Strahan, P. E. (2004). Risk management, capital structure and lending at banks. Journal of Banking \& Finance, 28(1), 19-43.

De Jonghe, O. \& Öztekin, Ö. (2015). Bank capital management: International evidence. Journal of Financial Intermediation, 24(2), 154-177.

Demarzo, P. M. \& Duffie, D. (1995). Corporate incentives for hedging and hedge accounting. Review of Financial Studies, 8(3), 743-771.

Diamond, D. W. \& Dybvig, P. H. (1983). Bank runs, deposit insurance, and liquidity. Journal of Political Economy, 91(3), 401-419.

Driscoll, J. C. \& Kraay, A. C. (1998). Consistent covariance matrix estimation with spatially dependent panel data. Review of Economics and Statistics, 80(4), 549-560.

Flannery, M. J. \& Rangan, K. P. (2006). Partial adjustment toward target capital structures. Journal of Financial Economics, 79(3), 469-506.

Frank, M. Z. \& Goyal, V. K. (2009). Capital structure decisions: which factors are reliably important? Financial Management, 38(1), 1-37.

Froot, K. A. \& Stein, J. C. (1998). Risk management, capital budgeting, and capital structure policy for financial institutions: an integrated approach. Journal of Financial Economics, 47(1), 55-82.

Gambacorta, L. \& Mistrulli, P. E. (2004). Does bank capital affect lending behavior? Journal of Financial Intermediation, 13(4), 436-457.

Gropp, R. \& Heider, F. (2010). The determinants of bank capital structure. Review of Finance, 14, 587-622

Harding, J. P., Liang, X. \& Ross, S. L. (2013). Bank capital requirements, capital structure and regulation. Journal of Financial Services Research, 43(2), 127-148.

Hart, O. \& Zingales, L. (2011). A new capital regulation for large financial institutions. American Law and Economics Review, 13(2), 453-490. 
Hausman, J. A. (1978). Specification tests in econometrics. Econometrica: Journal of the Econometric Society, 46(6), 1251-1271.

Hoechle, D. (2007). Robust standard errors for panel regressions with cross-sectional dependence. Stata Journal, 7(3), 281-312.

Jacques, K. \& Nigro, P. (1997). Risk-based capital, portfolio risk, and bank capital: A simultaneous equations approach. Journal of Economics and Business, 49(6),533-547.

Jokipii, T. \& Milne, A. (2008). The cyclical behaviour of European bank capital buffers. Journal of Banking \& Finance, 32(8),1440-1451.

Koziol, C. \& Lawrenz, J. (2009). What makes a bank risky? Insights from the optimal capital structure of banks. Journal of Banking \& Finance, 33(5), 861-873.

Mukherjee, S. \& Mahakud, J. (2010). Dynamic adjustment towards target capital structure: evidence from Indian companies. Journal of Advances in Management Research, 7(2), 250-266.

Muneer, S., Butt, B. Z. \& Rehman, K. U. (2011). A Multifactor Model of Banking Industry Stock Returns: An Emerging Market Perspective. Information Management and Business Review, 2(6), 267-275

Pesaran, M. H. (2004). General diagnostic tests for cross section dependence in panels. Cambridge Working Papers in Economics No. 435, University of Cambridge, and CESifo Working Paper Series No. 1229.

Rajan, R. G. \& Zingales, L. (1995). What do we know about capital structure? Some evidence from international data. The Journal of Finance, 50(5), 1421-1460.

Ramjee, A. \& Gwatidzo, T. (2012). Dynamics in capital structure determinants in South Africa. Meditari Accountancy Research, 20(1), 52-67.

Teixeira, J. C., Silva, F. J., Fernandes, A. V. \& Alves, A. C. (2014). Banks' capital, regulation and the financial crisis. The North American Journal of Economics and Finance, 28, 33-58.

Titman, S. \& Wessels, R. (1988). The determinants of capital structure choice. The Journal of Finance, 43(1),119. 